\title{
Iron, Copper, and Nickel Removal with Calcium Hydrogen Phosphate and Calcium Pyrophosphates in Solution
}

\author{
Hiroaki Onoda*, Kohei Sasaki \\ Department of Informatics and Environmental Sciences, Faculty of Life and Environmental Sciences, Kyoto Prefectural University, Japan
}

Copyright $@ 2017$ by authors, all rights reserved. Authors agree that this article remains permanently open access under the terms of the Creative Commons Attribution License 4.0 International License

\begin{abstract}
Calcium phosphate is an important material used in ion exchangers and adsorbents. In this work, calcium hydrogen phosphate dihydrate, $\mathrm{CaHPO}_{4} \cdot 2 \mathrm{H}_{2} \mathrm{O}$, was prepared from calcium nitrate solution and phosphoric acid. This phosphate transformed to calcium hydrogen phosphate un-hydrate, $\mathrm{CaHPO}_{4}$, by heating at $200^{\circ} \mathrm{C}$, and calcium pyrophosphate, $\mathrm{Ca}_{2} \mathrm{P}_{2} \mathrm{O}_{7}$, by heating at 400 and $700^{\circ} \mathrm{C}$. These calcium phosphates were used to remove trivalent iron cation, $\mathrm{Fe}^{3+}$ in solution. Samples without heating and those heated at $200^{\circ} \mathrm{C}$ indicated a high iron removal ratio. By the addition of these calcium phosphates and stirring for 5 minutes, a high ratio of iron cation was removed from the solution. This removal depended not only on the substitution of calcium to iron, but also on the precipitation of iron hydroxide. Calcium phosphates were also used to remove copper and nickel cations, $\mathrm{Cu}^{2+}$ and $\mathrm{Ni}^{2+}$. The removal ratios of copper and nickel cations were lower than those of iron cation.
\end{abstract}

Keywords Calcium Phosphate, Transition Metal, Purification of Water, Precipitation

\section{Introduction}

Phosphates have been used in ceramic materials, catalysts, adsorbents, fluorescent materials, dielectric substances, biomaterials, metal surface treatments, fertilizers, detergents, food additives, fuel cells, pigments, and other applications [1-8]. In these phosphate materials, calcium phosphate is an important compound used for many applications, such as in ion exchangers and adsorbents [9, 10]. These materials are useful to obtain clean water without harmful cations. Because calcium phosphates are high affinity for living organisms, they can be used as a filter to remove harmful ions from water. Furthermore, these materials are easy to synthesize without expensive apparatus. Therefore, the use of these materials is expected all over the world. However, these reports mainly concerned hydroxyapatite, $\mathrm{Ca}_{10}\left(\mathrm{PO}_{4}\right)_{6}(\mathrm{OH})_{2}$, and other phosphates were less reported.

There are however other kinds of calcium phosphates, for example, $\mathrm{Ca}_{3}\left(\mathrm{PO}_{4}\right)_{2}, \mathrm{CaHPO}_{4} \cdot 2 \mathrm{H}_{2} \mathrm{O}$, etc. [11-14]. The formation of these phosphates was affected from a $\mathrm{Ca} / \mathrm{P}$ mixing ratio of raw materials, heating temperature and time, additives, and so on [15-17]. Further, phosphate materials produce condensed phosphate in a dehydration reaction [18, 19]. These condensed phosphates have the possibility of having different properties than orthophosphate. Therefore, the study about these phosphates is required to obtain novel ion exchangers and adsorbents to remove harmful ions.

In our previous work, calcium hydrogen phosphates di-hydrate, $\mathrm{CaHPO}_{4} \cdot 2 \mathrm{H}_{2} \mathrm{O}$, were prepared with corbicula shells, and then used to remove iron cation in solution [20]. Iron cation was removed with this phosphate in this limited condition. Therefore, in the present work, we study the removal of transition metal cations with calcium hydrogen phosphates di-hydrate, calcium hydrogen phosphates, and calcium pyrophosphate, $\mathrm{Ca}_{2} \mathrm{P}_{2} \mathrm{O}_{7}$.

\section{Materials and Methods}

Calcium nitrate solution $(0.1 \mathrm{~mol} / \mathrm{L})$ was mixed with phosphoric acid $(0.1 \mathrm{~mol} / \mathrm{L})$, and then adjusted to $\mathrm{pH} 5$ and 7 with ammonia solution. The precipitates were filtered and dried. A part of the precipitates were heated at 200, 400, and $700^{\circ} \mathrm{C}$ for one hour. All chemicals were purchased from Wako Chemical Industries Ltd. (Osaka Japan), of commercial purity, and used without further purification.

The chemical composition of the powdered precipitates was determined using X-ray diffraction (XRD) and Infrared (IR) spectra. The XRD patterns were recorded on a Rigaku MiniFlex X-Ray diffractometer using monochromated $\mathrm{CuK} \alpha$ radiation. IR spectra of samples were recorded on a HORIBA FT-IR 720 (Horiba Ltd.) using the $\mathrm{KBr}$ disk method.

The substitution properties of the products were estimated using iron nitrate solutions. 5 and $10 \mathrm{mmol} / \mathrm{L}$ of 
iron (+III) nitrate solution was prepared at $\mathrm{pH} 3$ with sodium hydroxide. $0.1 \mathrm{~g}$ of the sample was added to this iron nitrate solution $(100 \mathrm{~mL})$, and stirred for five minutes. The resulting precipitates were filtered off. The filtered solution was estimated using ultraviolet-visible (UV-Vis) spectroscopy with a UV2100 spectrometer (Shimadzu Corp., $290 \mathrm{~nm}$ ). The $\mathrm{pH}$ values of the filtered solution were also measured.

Further, the removal of copper and nickel was also estimated. The calcium phosphate ( $\mathrm{pH} 5$, without heating) was added to $100 \mathrm{mmol} / \mathrm{L}$ of copper and nickel nitrate solutions $(50 \mathrm{~mL})$, and then stirred for $5,30,60,360$, and 1,440 min. The amount of calcium phosphate was determined to be in $\mathrm{Cu} / \mathrm{Ca}=1 / 1$ and $\mathrm{Ni} / \mathrm{Ca}=1 / 1$ conditions. The precipitates were filtered off. The filtered solution was estimated with a UV2100 spectrometer (Cu; 810nm, Ni; $410 \mathrm{~nm})$.

\section{Results and Discussion}

\subsection{Preparation of Calcium Phosphates}

Figure 1 shows XRD patterns of samples prepared at pH5 and then heated at several temperatures. Sample without heating indicated XRD pattern of calcium hydrogen phosphate di-hydrate, $\mathrm{CaHPO}_{4} \cdot 2 \mathrm{H}_{2} \mathrm{O}$. The peak pattern of calcium hydrogen phosphate un-hydrate, $\mathrm{CaHPO}_{4}$ was observed in a XRD pattern of samples heated at $200^{\circ} \mathrm{C}$. Samples heated at 400 and $700^{\circ} \mathrm{C}$ indicated the peaks of $\mathrm{Ca}_{2} \mathrm{P}_{2} \mathrm{O}_{7}$. From these results, samples are considered to form in the following reactions.

$$
\begin{gathered}
\mathrm{Ca}\left(\mathrm{NO}_{3}\right)_{2}+\mathrm{H}_{3} \mathrm{PO}_{4}+2 \mathrm{H}_{2} \mathrm{O} \\
\rightarrow \mathrm{CaHPO}_{4} \cdot 2 \mathrm{H}_{2} \mathrm{O}+2 \mathrm{HNO}_{3} \\
\mathrm{CaHPO}_{4} \cdot 2 \mathrm{H}_{2} \mathrm{O} \rightarrow \mathrm{CaHPO}_{4}+2 \mathrm{H}_{2} \mathrm{O} \\
2 \mathrm{CaHPO}_{4} \rightarrow \mathrm{Ca}_{2} \mathrm{P}_{2} \mathrm{O}_{7}+\mathrm{H}_{2} \mathrm{O}
\end{gathered}
$$

Samples prepared at $\mathrm{pH} 7$ showed the same patterns with samples prepared at $\mathrm{pH} 5$ and then heated at each temperature.

Figure 2 shows IR spectra of samples prepared at $\mathrm{pH} 5$ and then heated at several temperatures. The multiple peaks observed in the regions $1200-400 \mathrm{~cm}^{-1}$ of IR spectrum of non-heated sample can be due to P-O internal vibration in $\mathrm{CaHPO}_{4}$ [19]. The strong peaks at 1140, 1060, and $980 \mathrm{~cm}^{-1}$ are assigned to stretching vibration of the $\mathrm{P}-\mathrm{O}$ band. The peaks at 580 and $520 \mathrm{~cm}^{-1}$ are due to the O-P-O deformations. The sample without heating had an absorption peak at 1650 $\mathrm{cm}^{-1}$ due to water. This peak disappeared by heating at $200^{\circ} \mathrm{C}$. The sample heated at $400^{\circ} \mathrm{C}$ had similar spectra with that at $700^{\circ} \mathrm{C}$. The absorption peak at $720 \mathrm{~cm}^{-1}$ was due to P-O-P bonding in condensed phosphate [19]. These IR results correspond with the above XRD results.

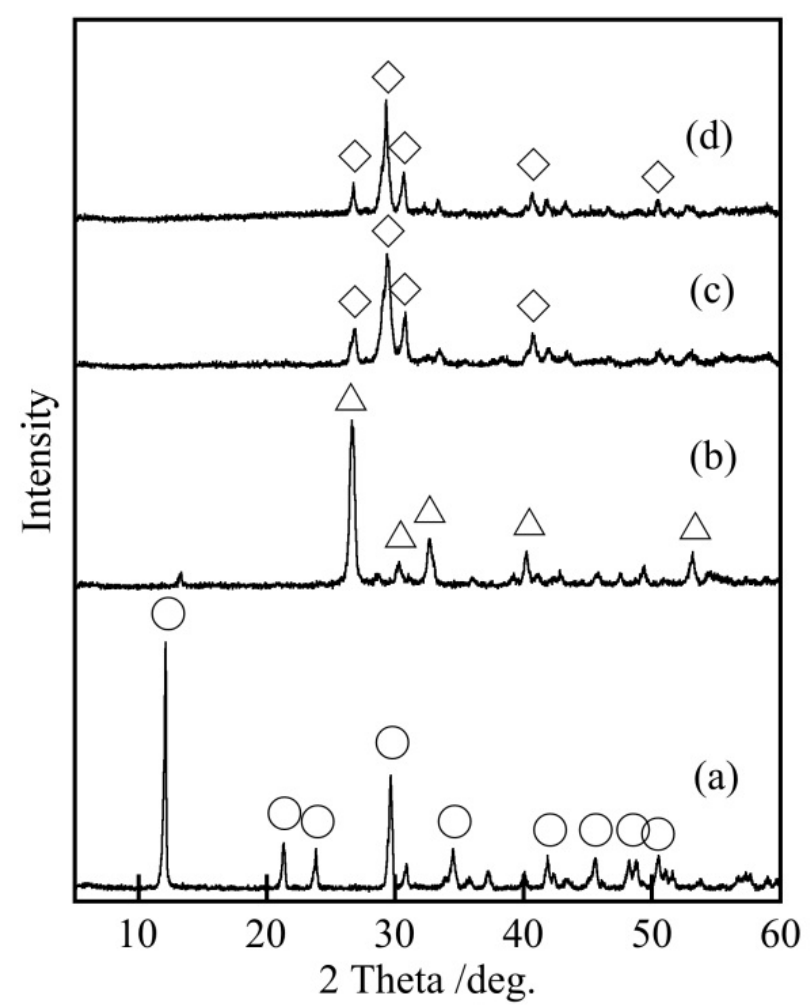

Figure 1. XRD patterns of samples prepared at $\mathrm{pH} 5$ and then heated at several temperatures, (a) R.T., (b) $200^{\circ} \mathrm{C}$, (c) $400^{\circ} \mathrm{C}$, and (d) $700^{\circ} \mathrm{C}$, $\circ$; $\mathrm{CaHPO}_{4} \cdot 2 \mathrm{H}_{2} \mathrm{O}, \Delta ; \mathrm{CaHPO}_{4}, \diamond ; \mathrm{Ca}_{2} \mathrm{P}_{2} \mathrm{O}_{7}$.

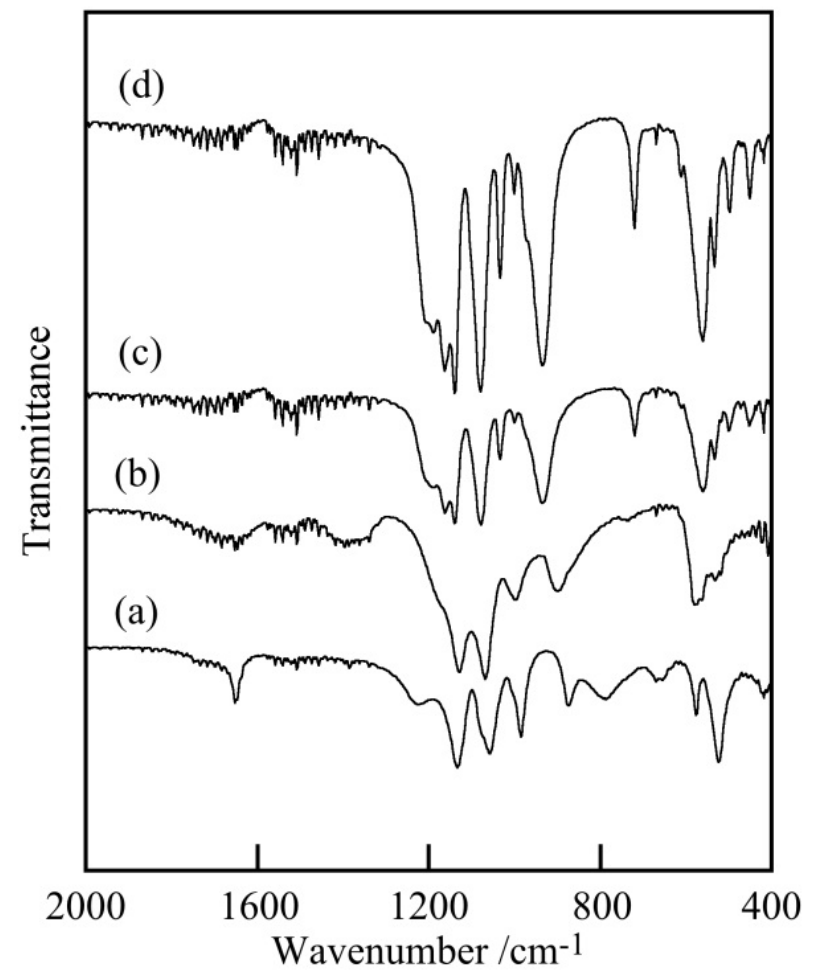

Figure 2. IR spectra of samples prepared at pH5 and then heated at several temperatures, (a) R.T., (b) $200^{\circ} \mathrm{C}$, (c) $400^{\circ} \mathrm{C}$, and (d) $700^{\circ} \mathrm{C}$. 


\subsection{Removal of Iron with Calcium Phosphate}

Table 1 shows the removal ratio of iron cation with calcium phosphates prepared in various conditions. Samples without heating indicate a higher removal ratio than $90 \%$. Because the main composition of these materials was $\mathrm{CaHPO}_{4} \cdot 2 \mathrm{H}_{2} \mathrm{O}, 0.1 \mathrm{~g}$ of samples included $5.81 \times 10^{-4} \mathrm{~mol}$ of calcium cation. On the other hand, 5 and $10 \mathrm{mmol} / \mathrm{L}$ of iron nitrate solutions $(100 \mathrm{~mL})$ included $5 \times 10^{-4}$ and $1 \times 10^{-3}$ mol of iron cation, respectively. In the conditions of $10 \mathrm{mmol} / \mathrm{L}$, the amount of removed iron cation was much higher than that of calcium cation in samples. Therefore, the removal of iron cation took place not only by the substitution from calcium to iron but also by precipitation of iron hydroxide. Table 2 shows the $\mathrm{pH}$ value of solutions after the iron removal process. Because samples were prepared at $\mathrm{pH} 5$ and 7, the $\mathrm{pH}$ value of solution increased from the original 3 by the addition of prepared calcium phosphates, then iron hydroxide was formed. Samples heated at $200^{\circ} \mathrm{C}$ also indicated higher removal ratio than $90 \%$. The amount of calcium cation in $0.1 \mathrm{~g}$ of sample was about $7.35 \times 10^{-4} \mathrm{~mol}$. Calculated from that the main composition was $\mathrm{CaHPO}_{4}$. In the conditions of $10 \mathrm{mmol} / \mathrm{L}$, iron hydroxide was also formed by samples heated at $200^{\circ} \mathrm{C}$. By heating at 400 and $700^{\circ} \mathrm{C}, \mathrm{CaHPO}_{4}$ transformed to $\mathrm{Ca}_{2} \mathrm{P}_{2} \mathrm{O}_{7}$ in equation (3). Because $0.1 \mathrm{~g}$ of $\mathrm{Ca}_{2} \mathrm{P}_{2} \mathrm{O}_{7}$ includes $7.87 \times 10^{-4} \mathrm{~mol}$, samples prepared at $\mathrm{pH} 5$ indicated lower than $78.7 \%$ in the condition of $10 \mathrm{mmol} / \mathrm{L}$. The difference between pH 5 and 7 appeared by heating at 400 and $700^{\circ} \mathrm{C}$. Because phosphate materials were sintered by heating, the reactivity of materials became lower. Therefore, the $\mathrm{pH}$ shift by the addition of samples prepared at $\mathrm{pH} 5$ became smaller and iron hydroxide was limited to form. This effect in a sample prepared at $\mathrm{pH} 7$ also became smaller; however, the removal ratio of iron cation was high. It is difficult to understand why this removal ratio is high in the condition treated with samples prepared at $\mathrm{pH} 7$.

Table 1. Removal ratios of iron cation with calcium phosphates prepared at $\mathrm{pH} 5$ and 7 and then heated at various temperatures $/ \%$

\begin{tabular}{|c|c|c|c|c|}
\hline & \multicolumn{2}{|c|}{$\mathrm{pH} 5$} & \multicolumn{2}{c|}{$\mathrm{pH} 7$} \\
\hline & $5 \mathrm{mmol} / \mathrm{L}$ & $10 \mathrm{mmol} / \mathrm{L}$ & $5 \mathrm{mmol} / \mathrm{L}$ & $10 \mathrm{mmol} / \mathrm{L}$ \\
\hline R.T. & 97.8 & 99.8 & 91.7 & 99.7 \\
\hline $200^{\circ} \mathrm{C}$ & 97.5 & 99.8 & 98.6 & 99.4 \\
\hline $400^{\circ} \mathrm{C}$ & 94.1 & 41.5 & 98.6 & 95.8 \\
\hline $700^{\circ} \mathrm{C}$ & 16.7 & 22.5 & 92.3 & 99.7 \\
\hline
\end{tabular}

Table 2. $\mathrm{pH}$ value of solution after iron removal process with calcium phosphates prepared at $\mathrm{pH} 5$ and 7 and then heated at various temperatures

\begin{tabular}{|c|c|c|c|c|}
\hline & \multicolumn{2}{|c|}{$\mathrm{pH} 5$} & \multicolumn{2}{c|}{$\mathrm{pH} 7$} \\
\hline & $5 \mathrm{mmol} / \mathrm{L}$ & $10 \mathrm{mmol} / \mathrm{L}$ & $5 \mathrm{mmol} / \mathrm{L}$ & $10 \mathrm{mmol} / \mathrm{L}$ \\
\hline R.T. & 5.73 & 6.21 & 6.00 & 6.00 \\
\hline $200^{\circ} \mathrm{C}$ & 5.79 & 5.66 & 5.99 & 6.00 \\
\hline $400^{\circ} \mathrm{C}$ & 3.62 & 3.65 & 5.87 & 5.85 \\
\hline $700^{\circ} \mathrm{C}$ & 3.50 & 3.28 & 2.87 & 2.92 \\
\hline
\end{tabular}

Figure 3 shows XRD patterns of samples prepared at $\mathrm{pH}$ 5 and then treated in an iron removal process $(10 \mathrm{mmol} / \mathrm{L})$. The peaks of $\mathrm{CaHPO}_{4} \cdot 2 \mathrm{H}_{2} \mathrm{O}$ and $\mathrm{CaHPO}_{4}$ in samples without heating and heated at $200^{\circ} \mathrm{C}$ disappeared by iron removal process, on the other hand the peaks of $\mathrm{Ca}_{2} \mathrm{P}_{2} \mathrm{O}_{7}$ in samples heated at 400 and $700^{\circ} \mathrm{C}$ became weak. By heating at 400 and $700^{\circ} \mathrm{C}$, the reactivity of samples became low, and the un-reacted $\mathrm{Ca}_{2} \mathrm{P}_{2} \mathrm{O}_{7}$ was detected in XRD analysis.

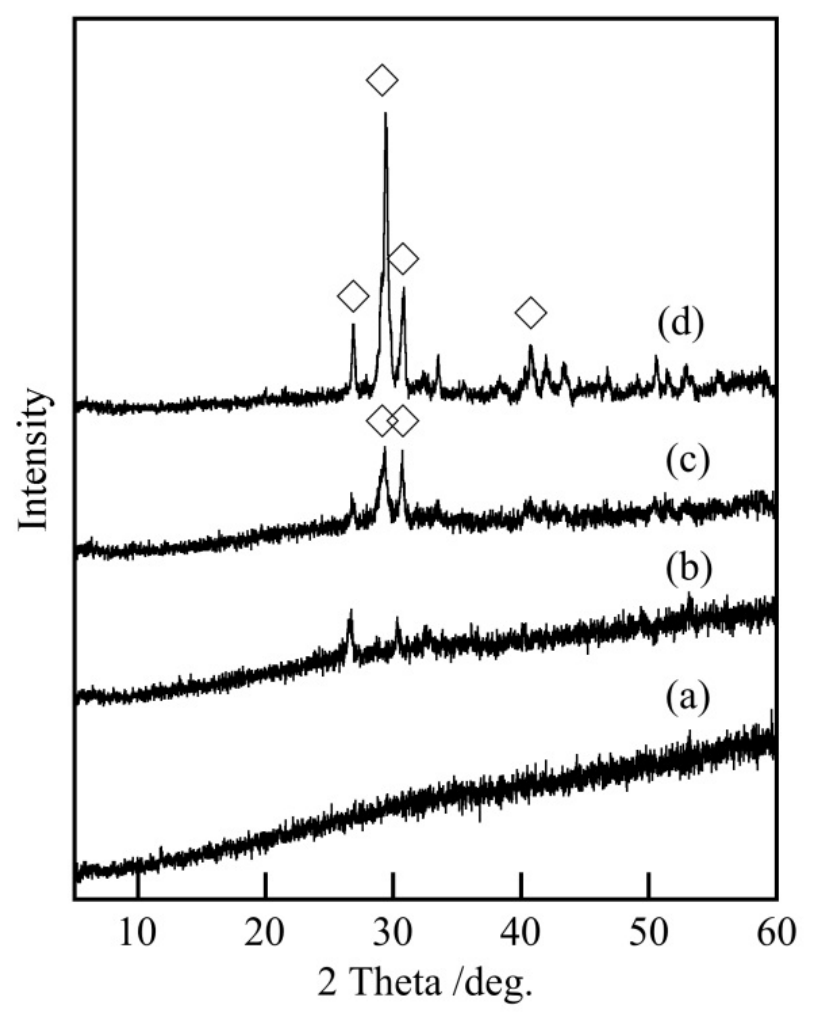

Figure 3. XRD patterns of samples prepared at $\mathrm{pH} 5$, heated at several temperatures, and then treated in Fe removal process (10 mmol/L), (a) R.T., (b) $200^{\circ} \mathrm{C}$, (c) $400^{\circ} \mathrm{C}$, and (d) $700^{\circ} \mathrm{C}, \diamond ; \mathrm{Ca}_{2} \mathrm{P}_{2} \mathrm{O}_{7}$.

\subsection{Removal of Copper and Nickel with Calcium Phosphates}

As another transition metal solution, we attempted to remove a copper solution. All conditions, with samples prepared at $\mathrm{pH} 5$ and 7, and then heated at several temperatures, indicated much smaller copper removal ratios than iron removal ratios. Because iron cation is trivalent, iron phosphate was easy to form the iron removal ratio became higher. On the other hand, copper cation is bivalent, copper phosphate was more difficult to form. Calcium phosphates showed difficulty removing the copper cation by stirring for $5 \mathrm{~min}$. Therefore, we studied stirring time as a means to remove copper cation. In addition, nickel solution was also studied. Table 3 shows the removal ratio of copper and nickel with samples prepared at $\mathrm{pH} 5$ (without heating). The removal ratio of copper at five minutes was $16.2 \%$ and those over $30 \mathrm{~min}$ indicated 51-56 \%. The removal of copper cation needs a large 
amount of time. On the other hand, the removal ratio of nickel cation was five percent lower until $360 \mathrm{~min}$. The removal rate was much different between copper and nickel. Because the ionic radius of copper was close to that of nickel, it is difficult to explain this difference from ionic radii.

Table 3. Removal ratio of $\mathrm{Cu}$ and $\mathrm{Ni}$ with samples prepared at $\mathrm{pH} 5 / \%$

\begin{tabular}{|c|c|c|}
\hline Time /min. & $\mathrm{Cu}^{2+}$ & $\mathrm{Ni}^{2+}$ \\
\hline 5 & 16.2 & 0.7 \\
\hline 30 & 51.7 & 0.8 \\
\hline 60 & 55.9 & 1.2 \\
\hline 120 & 53.5 & 3.8 \\
\hline 360 & 54.7 & 3.5 \\
\hline 1440 & 54.1 & 20.6 \\
\hline
\end{tabular}

\section{Conclusions}

Calcium hydrogen phosphate di-hydrate, $\mathrm{CaHPO}_{4} \cdot 2 \mathrm{H}_{2} \mathrm{O}$, was prepared from calcium nitrate solution and phosphoric acid. This phosphate transformed to calcium hydrogen phosphate un-hydrate, $\mathrm{CaHPO}_{4}$, by heating at $200^{\circ} \mathrm{C}$, and calcium pyrophosphate, $\mathrm{Ca}_{2} \mathrm{P}_{2} \mathrm{O}_{7}$, by heating at 400 and $700^{\circ} \mathrm{C}$. These calcium phosphates were used to remove iron, copper, and nickel cations in solution. Samples without heating and heated at $200^{\circ} \mathrm{C}, \mathrm{CaHPO}_{4} \cdot 2 \mathrm{H}_{2} \mathrm{O}$ and $\mathrm{CaHPO}_{4}$, indicated a high iron removal ratio. This removal depended not only on the substitution of calcium with iron but also on the precipitation of iron hydroxide. The removal ratios of copper and nickel cation with calcium phosphates were lower than those of iron cation.

\section{REFERENCES}

[1] A. Jain, A. M. Shore, S. C. Jonnalagadda, K. V. Ramanujachary, A. Mugweru, Conversion of fructose, glucose and sucrose to 5-hydroxymethyl-2-furfural over mesoporous zirconium phosphate catalyst, Applied Catalysis A, Vol. 489, 72-76, 2015.

[2] H. Yaacoubi, O. Zidani, M. Mouflih, M.Gourai, S. Sebti, Removal of Cadmium from water using Natural phosphate as Adsorbent, Procedia Engineering, Vol. 83, 386-393, 2014.

[3] Y. Cai, S. Feng, C. Ming, X. Ren, Y. Qin, L. An, Researching on thermal characters in $\mathrm{Yb}^{3+} / \mathrm{Er}^{3+}$ codoped phosphate glass ceramic for fluorescence temperature, Results in Physics, Vol. 6, 826-828, 2016.

[4] G. V. Rao, H. D. Shashikala, Optical, dielectric and mechanical properties of silver nanoparticle embedded calcium phosphate glass, Journal of Non-Crystalline Solids, Vol. 402, No.15, 204-209, 2014.

[5] J. S. Lee, W. L. Murphy, Functionalizing Calcium Phosphate Biomaterials with Antibacterial Silver Particles, Advanced
Materials, Vol. 25, No. 8, 1173-1179, 2013.

[6] A. Kalendova, D. Besely, M. Kohi, J. Stejskai, Effect of surface treatment of pigment particles with polypyrrole and polyaniline phosphate on their corrosion inhibiting properties in organic coatings, Progress in Organic Coatings, Vol. 77, No. 9, 1465-1483, 2014.

[7] F. Zhang, Q. Wang, J. Hong, W. Chen, C. Qi, L, Ye, Life cycle assessment of diammonium- and monoammoniumphosphate fertilizer production in China, Joumal of Cleaner Production, Vol. 141, 1087-1094, 2017.

[8] H. Onoda, A. Matsukura, Influence of $\mathrm{pH}$-Control in phosphoric acid treatment of titanium oxide and their powder properties, Materials Research Bulletin, Vol. 66, 151-155, 2015.

[9] D. P. Minh, N. D. Tran, A. Nzihou, P. Sharrock, Calcium phosphate based materials starting from calcium carbonate and orthophosphoric acid for the removal of lead(II) from an aqueous solution, Chemical Engneering Journal, Vol. 243, No. 1, 280-288, 2014.

[10] P. Pascaud, F. Errassifi, F. Brouillet, S. Sarda, A. Barroug, A. Legrouri, C. Rey, Adsorption on apatitic calcium phosphates for drug delivery: interaction with bisphosphonate molecules, Journal of Materials Science: Materials in Medicine, Vol. 25, 2373-2381, 2014.

[11] P. N. Kumar, S. K. Mishra, S. Kannan, Structural Perceptions and Mechanical Evaluation of $\beta-\mathrm{Ca}_{3}\left(\mathrm{PO}_{4}\right)_{3} / \mathrm{c}-\mathrm{CeO}_{2}$ Composites with Preferential Occupancy of $\mathrm{Ce}^{3+}$ and $\mathrm{Ce}^{4+}$, Inorganic Chemistry, Vol. 56, 3600-3611, 2017.

[12] A. C. Tas, Transformation of Brushite $\left(\mathrm{CaHPO}_{4} \cdot 2 \mathrm{H}_{2} \mathrm{O}\right)$ to Whitlockite $\left(\mathrm{Ca}_{9} \mathrm{Mg}\left(\mathrm{HPO}_{4}\right)\left(\mathrm{PO}_{4}\right)_{6}\right)$ or other $\mathrm{CaPs}$ in Physiologically Relevant Solutions, Journal of American Ceramic Society, Vol. 99, No. 4 1200-1206, 2016.

[13] A. E. Hamidi, R. M. Masamba, M. Khachani, M. Halim, S. Arsalane, Kinetics modeling in liquid phase sorption of copper ions on brushite di- calcium phosphate di-hydrate $\mathrm{CaHPO}_{4} \cdot 2 \mathrm{H}_{2} \mathrm{O}$ (DCPD), Vol. 56, No. 3, 779-791 (2015).

[14] R. L. Frost, Y. Xi, G. Millar, K. Tan, S. J. Palmer, Vibrational Spectroscopy of Natural Cave Mineral Monetite $\mathrm{CaHPO}_{4}$ and the Synthetic Analog, Spectroscopy Letters, Vol. 46, No. 1, 54-59 (2013).

[15] Z. Zyman, M. Epple, A. Goncharenko, D. Rokhmistov, O. Prymak, K. Loza, Thermally induced crystallization and phase evolution in powders derived from amorphous calcium phosphate precipitates with a $\mathrm{Ca} / \mathrm{P}$ ratio of $1: 1$, Journal of Crystal Growth, Vol. 450, No. 15, 190-196, 2016.

[16] Z. Zyman, M. Epple, A. Goncharenko, D. Rokhmistrov, O. Prymak, K. Loza, Peculiarities in thermal evolution of precipitated amorphous calcium phosphates with an initial $\mathrm{Ca} / \mathrm{P}$ ratio of $1: 1$, Journal of Materials Science: Materials in Medicine, Vol. 28, No. 3, 52, 2017.

[17] N. Nishikawa, T. Hasegawa, A. Miyake, Y. Tashiro, Y. Hashimoto, D. H. A. Blank, G. Rijnders, Relationship between the $\mathrm{Ca} / \mathrm{P}$ ratio of hydroxyapatite thin films and the spatial energy distribution of the ablation laser in pulsed laser deposition, Materials Letters, Vol. 165, No. 15, 95-98, 2006.

[18] V. C. Ghantani, M. K. Dongare, S. B. Umbarkar, Nonstoichiometric calcium pyrophosphate: a highly efficient and selective catalyst for dehydration of lactic acid to acrylic 
acid, RSC Advances, Vol. 4, No. 63, 33319-33326, 2014.

[19] R. Mulongo-Masamba, T. E. Kassri, M. Khachani, S. Arsalane, M. Halim, A. E. Hamidi, Synthesis and thermal dehydroxylation kinetic of anhydrous calcium phosphate monetite $\mathrm{CaHPO}_{4}$, Journal of Thermal Analysis and
Calorimetry, Vol. 124, 171-180, 2016.

[20] H. Onoda, S. Yamazaki, Homogenous hydrothermal synthesis of calcium phosphate with calcium carbonate and corbicula shells, Journal of Asian Ceramic Societies, Vol. 4, No. 4, 403-406, 2016. 